\title{
$\mathrm{RC}$ 建築物における座屈拘束筋違の制振効果および接合部設計法
}

\author{
- 鉄筋コンクリート骨組への座屈拘束筋違の活用に関する研究 その 3 -
}

\section{SEISMIC RESPONSE CONTROL OF SUPER HIGH-RISE RC BUILDINGS UTILIZING BUCKLING RESTRAINED BRACES AND THE DESIGN OF BRACE CONNECTIONS}

- Applications of buckling restrained braces in reinforced concrete frames Part 3 -

\author{
毎田悠承*1, 前川利雄 ${ }^{* 2}$, 出水俊彦*3, 濱田 真*4, \\ 曲哲*5, 吉敷祥 一 ${ }^{* 6}$, 坂田弘安 ${ }^{* 7}$, 和田章*8 \\ Yusuke MAIDA, Toshio MAEGAWA, Toshihiko DEMIZU, \\ Makoto HAMADA, Zhe QU, Shoichi KISHIKI, \\ Hiroyasu SAKATA and Akira WADA
}

\begin{abstract}
In this paper, the seismic response control of buckling restrained braces (BRBs) in RC buildings subjected to earthquake ground motions is investigated by nonlinear time history analysis. In one model, the RC frame was braced by BRBs in each story (each model) and in the other one, each BRB spanned over two stories (over model). As a result of the analysis, the over model exhibited almost the same seismic response control as compared to the each model, although the number of BRBs was significantly reduced and the RC beams in the braced span were abandoned. In addition, the seismic response control of BRBs in RC buildings is investigated by FE analysis. Finally, the design of brace connections was suggested from the test and analysis result.
\end{abstract}

Keywords : RC buildings, buckling restrained brace, cotter, anchor PC rod, seismic response analysis, finite element analysis $\mathrm{RC}$ 建築物, 座屈拘束筋違, コッター, アンカー PC 鋼棒, 地震応答解析, 有限要素解析

1. 序

我が国における建築物の超高層化の傾向は 1990 年代から見られ, 当初は事務所建築を中心とする非住居系の建築物が多く，鉄骨構造 が中心であった. 2000 年代に入ると都市部においてマンションのよ うな住居系の超高層鉄筋コンクリート（以下， RC）建築物が急増 してきた ${ }^{1)}$ 。超高層 RC 建築物では下層階柱には大きな長期軸力，さ らに地震時に変動軸力が生じることになり, 設計上の懸念事項とな るが，建設が始まった当初からこれらの問題に対しては実験および 解析によって様々な解決策が検討されてきた $\left.{ }^{21}, 3\right)$ 杖。.また，近年で は大きな軸力に対処するために高強度のコンクリート，鉄筋を用い た高強度 RC 部材が求められ，それらの性能を評価する構造実験も 行われており ${ }^{4)}$, 今後も超高層 RC 建築物の増加が予想される. 純 ラーメン構造の超高層 RC 建築物では主架構が大地震時に大きな塑 性変形を受けることになり，コンクリートのひび割れや，主筋の塑 性化によって継続使用が問題となる。 そこで, 最近の超高層 RC 建 築物では制振構造を採用し， RC 骨組の損傷制御および居住空間の
フレキシビリティの確保が求められている5 ${ }^{5}$. 以上のような背景か ら, 筆者らはRC 骨組に座屈拘束筋違（以下， BRB）を組み込むこ とで耐震安全性, およびエネルギ吸収性能の向上を図る研究を推進 してきた 6)，7）离と。超高層 RC 建築物に制振装置を通常の設置形式を 用いて取り付けた場合，上層部では曲げ変形が卓越するため，制振 効果がほとんど期待できないとされている5）が，その問題を解決 するためにオイルダンパーを用いた新たな構造システムの検討も行 われている5 ${ }^{5}$.

本論文では，まず立体フレームモデルによって BRB を組み込ん だ超高層 RC 建築物の地震応答解析を行い，筆者らが提案している ワーレントラス状の設置形式を用いて BRB を組み込んだ超高層 RC 建築物の地震応答性状を確認する。また，既報7)で作成した有限 要素解析モデルを用いて，本設置形式の制振効果を評価する，最後 に，これまで実験および解析による検討を進めてきたコッターとア ンカーPC 鋼棒を用いた BRB 接合部に関して更なる検討を重亦，具 体的な設計法としてまとめる.

\footnotetext{
*1 千葉大学大学院工学研究科建築 - 都市科学専攻 助教 · 博士 (工学)

*2 熊谷組技術研究所建築構造研究グループ グループ部長・工修

*3 佐藤工業技術研究所 主席研究員 · 工修

*4 熊谷組技術研究所 副所長.工修

*5 中国地震局工程力学研究所 准研究員 $\cdot$ Ph.D

*6 東京工業大学建築物理研究センター 准教授. 博士 (工学)

*7 東京工業大学大学院理工学研究科建築学専攻 教授·工博

*8 東京工業大学 名誉教授. 工博
}

Assistant Prof., Dept. of Architecture, Chiba University, Dr. Eng.

General Manager, Architectural Structure Research Group, Technical Research \& Development Institute, KUMAGAI GUMI Co., Ltd., M. Eng.

Principal Researcher, Technical Research Institute, Satokogyo Co., Ltd., M. Eng. Deputy General Manager, Technical Research \& Development Institute, KUMAGAI GUMI Co., Ltd., M. Eng.

Associate Researcher, Institute of Engineering Mechanics, CEA, Ph. D. Associate Prof., Structural Engineering Research Center, Tokyo Tech, Dr. Eng. Prof., Dept. of Architecture and Building Engineering, Tokyo Tech, Dr. Eng. Prof., Emeritus, Tokyo Tech, Dr. Eng. 


\section{2. 地震応答解析概要}

\section{1. 検討建築物}

検討に使用する建築物は，試設計された超高層 $\mathrm{RC}$ 建築物 ${ }^{8)}$ とし て，地上 36 階建て， $5 \times 5$ スパンの 2 軸対称で整形なものである。 ス パン長は $6 \mathrm{~m}$ の均一スパン, 階高は梁下内法高さを $2.3 \mathrm{~m}$ とした. 使 用材料はコンクリート Fc30～60, 主筋 SD490（D29～41）, せん断 補強筋 SD295A，USD785（D13）とした。伏図を図 1 に，軸組図を図 2 に, コア部周囲の部材断面を図 3 に, 他の部材断面を表 1 に示寸. これを基本建築物とし，X 方向に設置する BRB の設置形式をパラ メータとした解析を行った。 なお, 検討方向は $\mathrm{X}$ 方向とした。

\section{2. 解析モデル}

解析には，汎用ソフト midas Gen Ver.8309) を用いた．解析モデルは, 1 階柱脚を固定とした立体フレームモデルとした。柱および梁部材 の復元力特性には，修正武田モデルを用いた。減衰は瞬間剛性比例 型として, 減衰定数 $h=0.03$ とした. BRB はトラス要素としてモデル 化し，復元力特性はバイリニア型とした。

\section{3. 解析パラメータおよび架構計画}

解析パラメータを表 2 に示す. 基本建築物の中央コア部を吹き抜 けとし，図 1 に示す各層の BRB 設置構面に 1 本ずつ BRB を設置した モデル（図４（a））(以下，each モデル)，および2 層をまたぐ形で BRB を設置したモデル（図4（b）および図 5）（以下，over モデル）

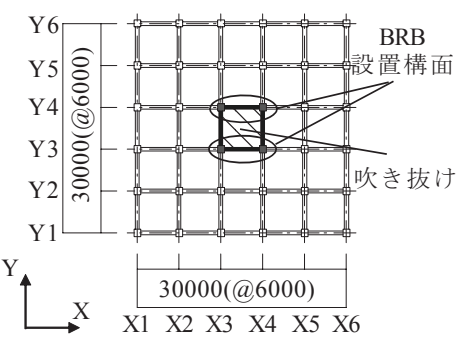

図 1 伏図 (単位 $[\mathrm{mm}]$ )

\begin{tabular}{c|c|c|c}
\multicolumn{2}{c}{ 表 2} & \multicolumn{4}{c}{ 解析パラメータ } \\
\hline モデル名 & 基本 & each & over \\
\hline \hline BRB設置 & 無 & 各層 & 2層またぎ \\
\hline コア部床 & 有 & \multicolumn{2}{|c}{ 吹き抜け } \\
\hline コア部周囲の柱 & \multicolumn{2}{|c|}{ 通常 } & 剛強 \\
\hline コア部周囲の梁 & \multicolumn{2}{|c|}{ 通常 } & 軽微な鉄骨梁 \\
\hline 1次固有周期 $[\mathrm{s}]$ & 2.92 & 2.77 & 2.77 \\
\hline
\end{tabular}

の計 2 種の制振建築物モデルを作成した。 over モデルの架構計画に ついて以下に述べる。筆者らが提案してきた BRB 接合部 6)，7) では

表 1 柱 ·梁断面リスト（基本建築物）

\begin{tabular}{c|c|c|c|c|c|c|c}
\hline \multicolumn{3}{c|}{ 梁（中フレーム） } & \multicolumn{4}{c}{ 柱（中柱） } \\
\hline 層 & $b[\mathrm{~mm}]$ & $D[\mathrm{~mm}]$ & $p_{\mathrm{t}}[\%]$ & 層 & $b[\mathrm{~mm}]$ & $D[\mathrm{~mm}]$ & $p_{\mathrm{g}}[\%]$ \\
\hline \hline $31 \sim \mathrm{R}$ & 550 & 800 & 0.88 & $33 \sim 36$ & 800 & 800 & 1.61 \\
\hline $25 \sim 30$ & 550 & 850 & 1.02 & $30 \sim 32$ & 800 & 800 & 1.99 \\
\hline $22 \sim 24$ & 550 & 850 & 1.23 & $21 \sim 29$ & 800 & 800 & 2.39 \\
\hline $18 \sim 21$ & 550 & 850 & 1.38 & $11 \sim 20$ & 900 & 900 & 1.89 \\
\hline $1 \sim 17$ & 550 & 900 & 1.38 & $1 \sim 10$ & 1000 & 1000 & 1.82 \\
\hline
\end{tabular}

$\left(b\right.$ :幅, $D:$ せい, $p_{\mathrm{t}}$ :引張鉄筋比, $p_{\mathrm{g}}$ : 全主筋比 $)$

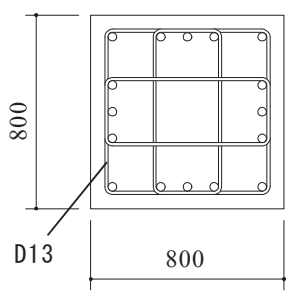

$16-D 35$

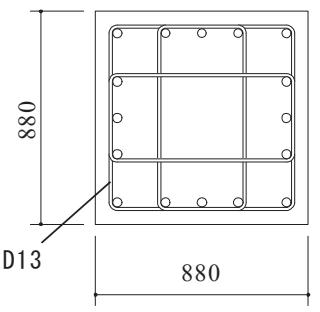

16-D38 基本建物, each モデル over モデル $21 \sim 23$ 階柱

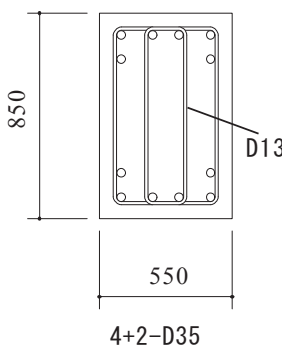

基本建物, each モデル

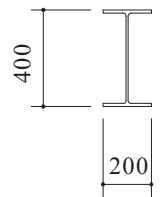

$\mathrm{H}-400 \times 200 \times 8 \times 13$ over モデル
$22 \sim 24$ 階梁

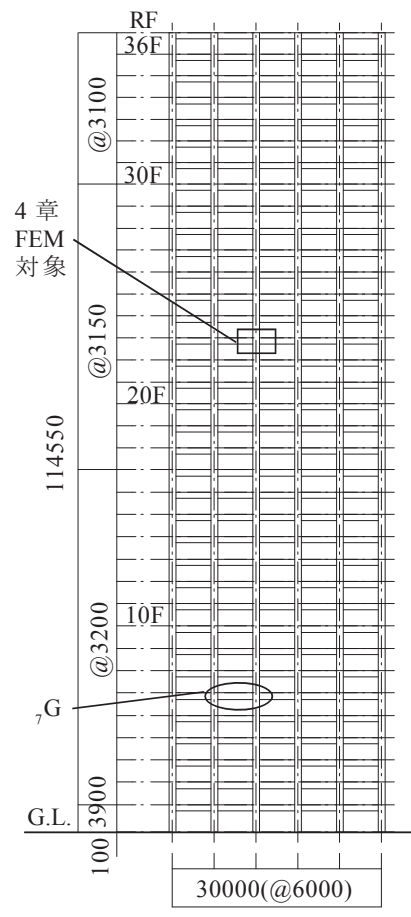

図 2 軸組図(単位 $[\mathrm{mm}]$ )

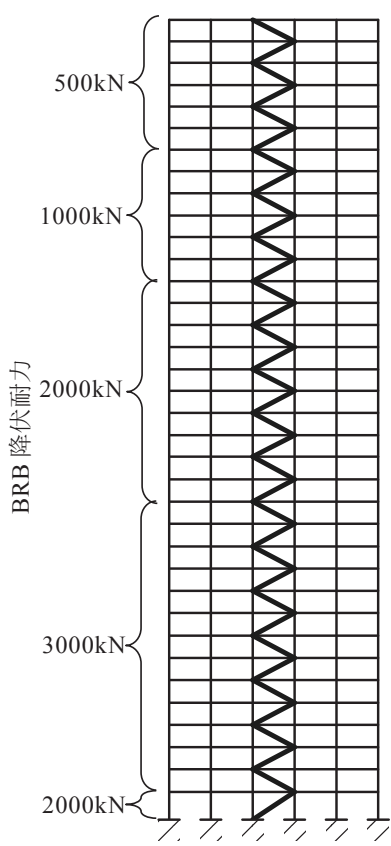

(a) each モデル

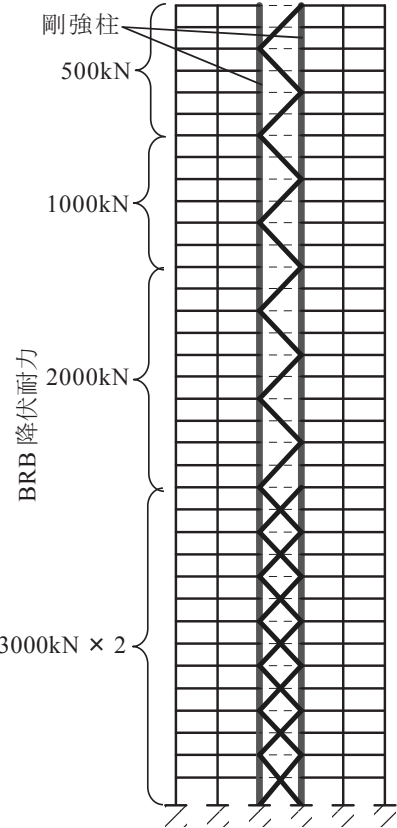

(b) over モデル
図 4 解析モデル

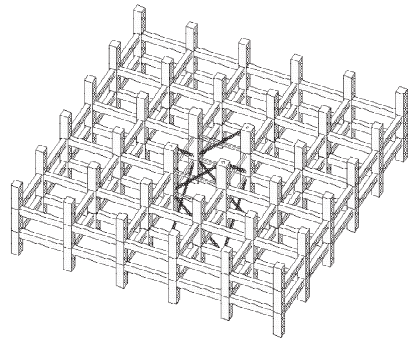

図 5 設置形式詳細（over モデル）

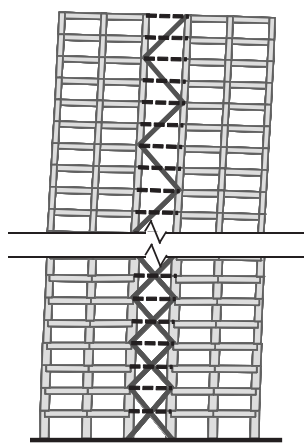

図 6 模式図 
中央コア部周囲の梁部材は軽微な鉄骨梁に変更できる.これは上下 層に同じ降伏耐力の B R B を設置すれば, トラスのゼロ力部材に相 当する梁は長期荷重を支持するだけの部材（スラブ受け）とするこ とができるためである ${ }^{6)}$. 本解析では両端ピン支持の H-400 × 200 $\times 8 \times 13 （ \mathrm{SN} 400 ）$ でスラブ受けをモデル化した. 中央コア部周囲 の梁を軽微な部材にして, さらに over モデルの方が 2 層分の層間変 形によって, 約 2 倍の BRB 節点間の変形が生じるため, 図 6 に示寸 ように上層階での B R B の変形を増大させ, 2 層またぎに設置した BRB を有効に機能させることができると考えられる. また, BRBの 設置に伴う柱の軸力変動を処理するためにコア部周囲は剛強な RC 骨組（柱の断面積および鉄筋量を約 1.2 倍）によって構成した. 各 階の BRB 降伏耐力を図 4 中に示寸。 over モデルでは 14 階までの下層 階では強度・剛性を確保する目的でBRB をたすき掛けとして密に 配置し, 中層階より上部では効率的なエネルギ吸収を意図して2 層 またぎで 1 本ずつ配置している. また, 上下層 BRB の降伏耐力に差 がある層もあるが, 実験にて BRB 取り付け部をアンカーPC 鋼棒で 締め付けることで対応できることが確認されている77. over モデル
のBRB の降伏耐力は, each モデルと架構の 1 次固有周期がほぼ等し くなるように設定した. 各モデルの固有周期を表 2 に示す. 各モデ ルで, RC 骨組と BRB の接合部は剛とした.

\section{4. 検討用入力地震動}

入力地震動として, 観測地震動記録の標準 3 種（EL Centro NS, Taft EW, Hachinohe NS), および告示模擬地震動 3 種（位相は八戸, 神戸, 乱数）の計 6 種の地震動波形をそれぞれ $\mathrm{PGV}=50,75 \mathrm{~cm} / \mathrm{s}$ に基準化し て用いた。

\section{3. 地震応答解析結果}

\section{1. 最大応答層間変形角}

解析より得られた各建築物モデルにおける高さ方向の最大応答層 間変形角 $R$ 分布を図 7 に示寸.

each モデル, over モデルの制振構造とした建築物ではいずれの地 震波においても $\mathrm{PGV}=50 \mathrm{~cm} / \mathrm{s}$ で $R=1 / 150 \mathrm{rad} ., \mathrm{PGV}=75 \mathrm{~cm} / \mathrm{s}$ で $R=1 / 100 \mathrm{rad}$. 以内の応答に抑えられ, 基本建築物よりも最大応答層間変形角は低 減したことが確認された。 each モデルと over モデルを比較すると,
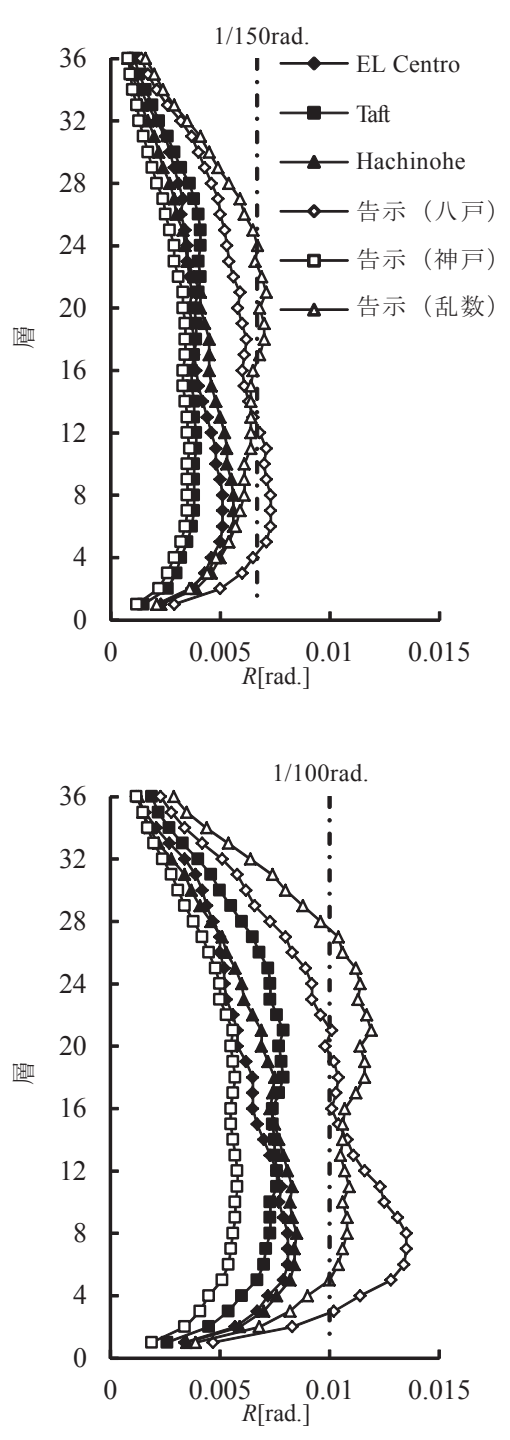

（a）基本建築物

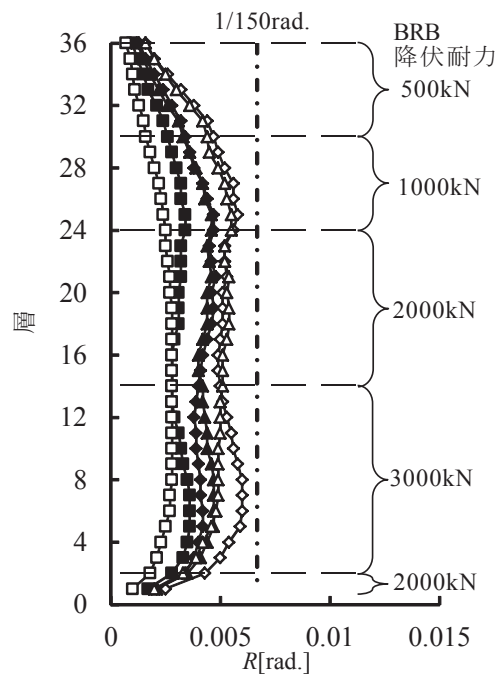

(i) $P G V=50 \mathrm{~cm} / \mathrm{s}$

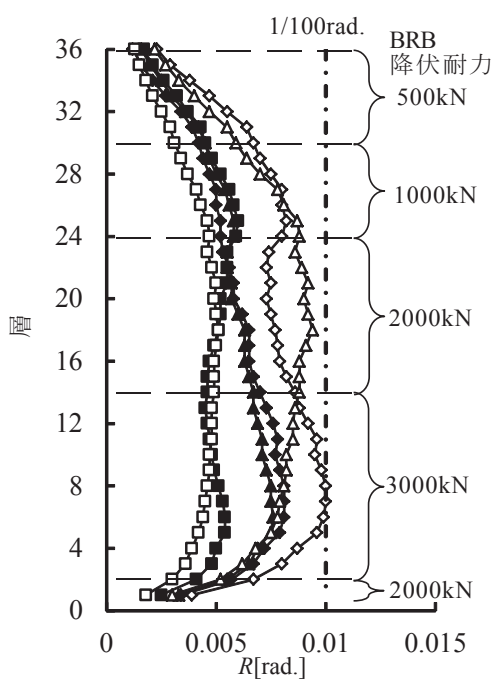

(ii) $\mathrm{PGV}=75 \mathrm{~cm} / \mathrm{s}$

(b) each モデル

図 7 最大応答層間変形角
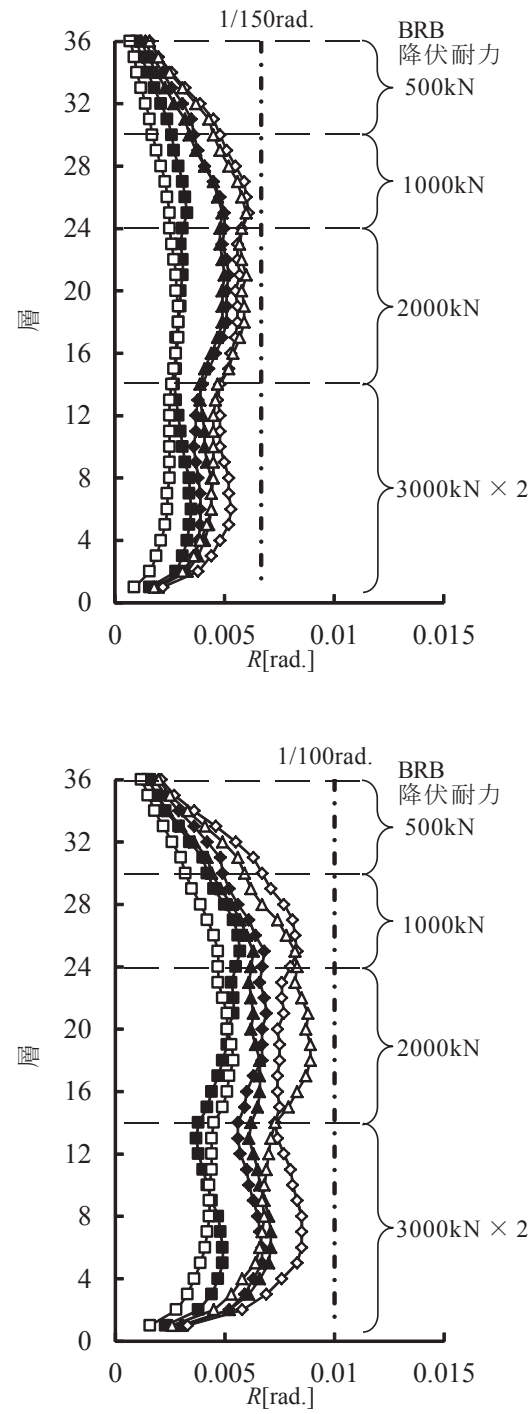

（c）over モデル 
14 層までの下層部では over モデルの応答低減効果が高い. over モデ ルの 14 層まではBRB を 2 層またぎで 2 本ずつ設置しており, each モ デルと同じ数量の B R B でより高い応答低減効果が発揮されたこと が分かる．上層部では over モデルの方がやや応答が大きい傾向にあ るがほぼ同等の応答層間変形角となっている。 over モデルでは, each モデルに比較して, BRB の設置数を減らし, かつ RC 梁を省略 しても, ほぼ同等の応答低減効果が確保されており, 本架構計画は より合理的であると言える。

\section{2. 梁の履歴挙動}

基本建築物における応答層間変形角が最大であった図 2 中の 7 層 $\mathrm{Y} 3$ 通りの梁 $\left({ }_{7} \mathrm{G}\right)$ の告示波 (八戸) $(\mathrm{PGV}=75 \mathrm{~cm} / \mathrm{s})$ に対する応答曲 げモーメント $M$ 一回転角 $\theta$ 関係を図 8 に示寸。また, 各モデルにお ける梁の塑性率 $\mu_{\mathrm{r}}$ を表 3 に示す.

図 8 から, 基本建築物および each モデルでは梁主筋が降伏したこ とが見て取れる. 塑性率も基本建築物では $\mu_{\mathrm{r}}=1.34$ となっており, 塑 性化したことが分かる. each モデルでは塑性率 $\mu_{\mathrm{r}}=1.09$ であり, 基本 建築物よりも変形を $25 \%$ 抑制できている。，一方，over モデルでは塑 性率 $\mu_{\mathrm{r}}=0.92$ まで抑えられており弾性範囲である. 基本建築物に比 ベて $42 \%$, each モデルと比較しても $17 \%$ 変形が低減できた。 したがっ て， BRB を組み込むことで RC 骨組の変形が低減できたと言える。 ま た, 通常用いられる各層に BRB を設置する形式よりも, 筆者らが 提案したover モデルの方が変形低減効果が大きい.

\section{3. BRB の履歴挙動およびエネルギ吸収量}

次いで, 23 層（over モデルでは 23，24層をまたぐ） Y3 通りの BRB の告示波（八戸） $(\mathrm{PGV}=50 \mathrm{~cm} / \mathrm{s} ）$ および告示波（乱数） $(\mathrm{PGV}=75 \mathrm{~cm} / \mathrm{s}$ ) に対する応答軸力 $N_{\mathrm{BRB}}$ 一軸方向変位 $\delta_{\mathrm{BRB}}$ 関係を図 9 に, BRB の塑性 率 $\mu_{\mathrm{BRB}}$ を表 4 に示寸. いずれの BRB も降伏耐力は $2000 \mathrm{kN}$ であり, 図 9 中には降伏耐力も併せて示している. また, BRB の累積エネルギ 吸収量を図 10 に示寸。縦軸にエネルギ吸収量 $W_{\mathrm{BRB}}$ を, 横軸に時間 $t$ を示している.

告示波（八戸） $(\mathrm{PGV}=50 \mathrm{~cm} / \mathrm{s})$ に対して each モデルの BRB は $\mu_{\mathrm{BRB}}=0.92$ と塑性化していない. 一方, over モデルでは $\mu_{\mathrm{BRB}}=1.72$ とエネルギ 吸収を行っている. 告示波 (乱数) $(\mathrm{PGV}=75 \mathrm{~cm} / \mathrm{s})$ に対しても, each モデルよりも over モデルの方が大きな履歴ループを示している. エ ネルギ吸収量に着目すると地震終了時までに each モデルでは $49 \mathrm{kNm}$ であるのに対し，over モデルでは $481 \mathrm{kNm}$ である。 over モデルでは 2 層分のエネルギ吸収量であるため, 1 層に寄与寸るのはその半分 と考えても $240 \mathrm{kNm}$ であり, each モデルの約 5 倍のエネルギ吸収を 行っている. これは, over モデルの方が 2 層分の層間変形によって,

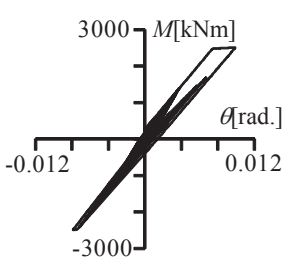

(a) 基本建築物

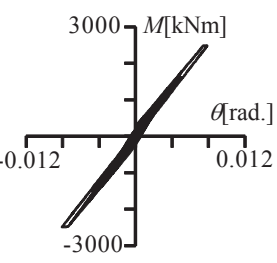

(b) each モデル

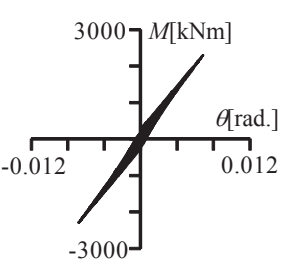

(c) over モデル
図 8 梁の履歴挙動

表 3 梁の塑性率 $\mu$
2 倍近くの軸変形が生じているためであると考えられる。実際には each モデルのように 1 層 $(3150 \mathrm{~mm}) 1$ スパン $(6000 \mathrm{~mm})$ に取り付け ると BRB の部材長さ $L$ は $6777 \mathrm{~mm}$ であり, over モデルのように 2 層 $(6300 \mathrm{~mm}) 1$ スパン $(6000 \mathrm{~mm})$ に取り付けると BRB の部材長さ $L$ は $8700 \mathrm{~mm}$ となるため, 同じ塑性化部の断面積 $A_{\mathrm{p}}$, ヤング係数 $E_{\mathrm{s}}$ の BRB を使用しても，軸剛性 $E_{\mathrm{s}} A_{\mathrm{p}} / L$ は over モデルの方が each モデルに比べ て約 $22 \%$ 低くなってしまう。しかしながら, over モデルの方が 2 層

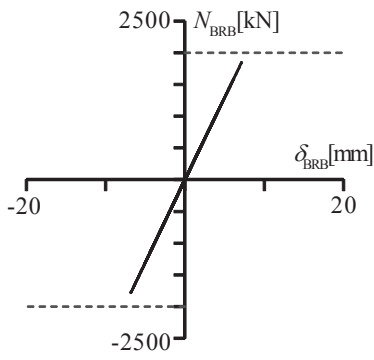

(a) each モデル

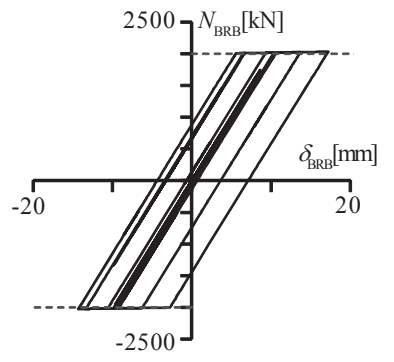

(b) over モデル （i）告示波 (八戸) $(P G V=50 \mathrm{~cm} / \mathrm{s})$

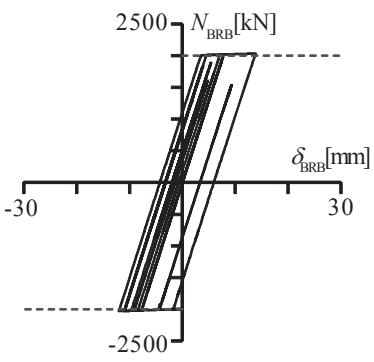

(a) each モデル

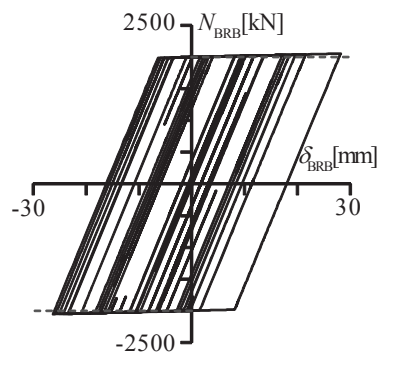

(b) over モデル (ii) 告示波 (乱数) $(P G V=75 \mathrm{~cm} / \mathrm{s}$ )

図 9 BRB の履歴挙動

表 4 BRB の塑性率 $\mu_{\text {BRB }}$

\begin{tabular}{c|c|c}
\hline & each & over \\
\hline \hline 告示波 $(八 戸)(\mathrm{PGV}=50 \mathrm{~cm} / \mathrm{s})$ & 0.92 & 1.72 \\
\hline 告示波(乱数) $(\mathrm{PGV}=75 \mathrm{~cm} / \mathrm{s})$ & 1.77 & 2.81 \\
\hline
\end{tabular}

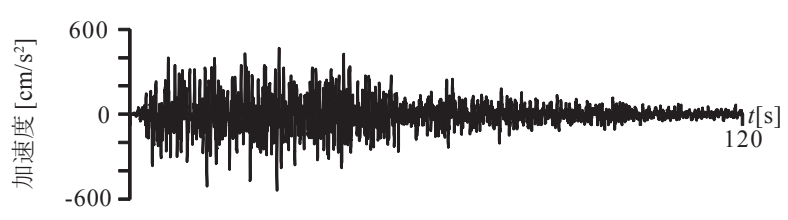

（i）入力加速度の時刻歴波形 告示波（乱数） $(\mathrm{PGV}=75 \mathrm{~cm} / \mathrm{s}$ )

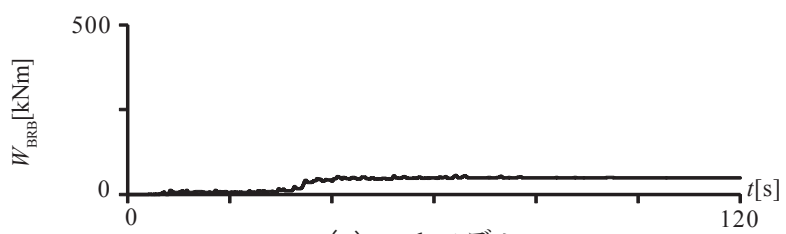

(a) each モデル

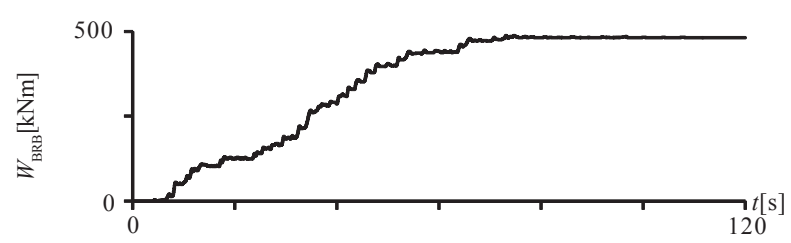

(b) over モデル

（ii）BRBの累積エネルギ吸収量

図 10 BRB の累積エネルギ吸収量 
分の層間変形によって, 約 2 倍の BRB 節点間の変形が生じるため, 早期に降伏寸る。したがって, over モデルのように2 層をまたぐよ うにBRB を設置することで, BRB の変形を増大させることができ, 上層部においても有効に機能させることができたと考えられる.

\section{4. 有限要素解析による制振効果の検討}

前章では, 本論文で提案した over モデルの合理性を, 立体フレー ムモデルによる地震応答解析から検討した．2 層をまたぐ形で BRB を設置した over モデルは, 各層にBRB を設置した each モデルに比較 して, RC 骨組の変形抑制および BRB のエネルギ吸収性能向上に効 果的であることが分かった。本章ではその結果を踏まえ, 既報7)で 作成した有限要素解析モデルを用いて, over モデルの BRB 設置形式 を用いた $\mathrm{RC}$ 部分架構の損傷制御効果や等価粘性定数 $h_{\mathrm{eq}}$ などの制振 効果を詳細かつ定量的に評価することを目的とする.

\section{1. 有限要素解析概要}

\section{【使用プログラム】}

解析には汎用有限要素法プログラム FINAL Ver.1110) を用いた。

\section{【使用要素】}

$\mathrm{RC}$ 骨組への BRB 接合方法には筆者らが提案してきたコッターと とアンカー PC 鋼棒を用いる方法6)，7）皂をを採用した。 コンクリート， エンドプレート, ガセットプレート（以下, G.PL) には四辺形要素 を, 鉄筋にはトラス要素を用いた. BRB は心材部分の軸剛性, 曲げ 剛性を考慮した梁要素でモデル化した．G.PL と BRB 間のボルト接 合部は，節点を共有させモデル化した．また，ボルト接合部は 2 次 元モデルで再現するために, 要素の厚さを部材断面積と等しくする ことで表現した. アンカーPC 鋼棒の緊張力導入については, アン
カーPC 鋼棒をトラス要素でモデル化し, 初期応力を導入した。ま た, G.PL とコンクリートの間にはライン要素を挿入して, せん断, 圧縮, 引張特性を与えた。なお, 本解析モデルの有効性は実験結果 との比較から確認できている ${ }^{71}$.

\section{【解析対象モデル】}

前章に示した基本建築物と over モデルの 2 種について, 図 11 に 示すように要素分割して解析を行った。いずれのモデルも図 2 中に 示す 23 層 X3, Y 3 交点を中心に半層, 半スパンを取り出した十字 骨組（over モデルではスパン右側はBRB）とした．断面詳細は図 3 に示している.

\section{【載荷・境界条件】}

基本建築物の境界条件は両側の梁端部をローラー支持, 柱脚をピ ン支持とし，載荷は柱頭に強制変位を与えた。 over モデルの境界条 件・載荷方法の詳細を図 12 に示す。柱頭, 柱脚, 梁端および上層 $\mathrm{BRB}$ 上端をローラー支持, 下層 BRB 下端をピン支持とし, 載荷は図 12 に示寸層間変形角 $R$ とそれぞれのローラー支持部の変位の関係 から強制変位 $\delta_{1} \sim \delta_{4}$ を与えた. 有限要素解析モデルに与える強制変 位は, 前章の地震応答解析から得られた告示波（八戸） $(\mathrm{PGV}=75 \mathrm{~cm} /$ $\mathrm{s})$ に対するそれぞれのモデルの応答層間変位（ $t=0 \sim 30 \mathrm{~s} ）$ とした. なお， RC 骨組の損傷制御効果および制振効果を安全側に評価する ために柱の軸力は導入していない.

\section{【材料構成則】}

(1) コンクリート

コンクリートの主応力度一等価一軸ひずみ度関係を図 13 に示す. 引張側はひび割れまで線形を仮定し，ひび割れ後は出雲モデル11) により引張軟化特性を考慮した。一方, 圧縮側は最大強度までは修

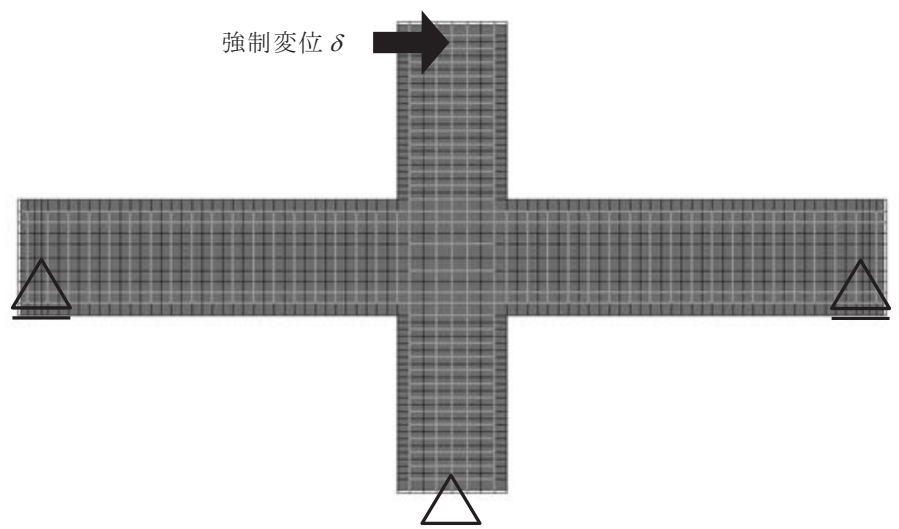

(a) 基本建築物

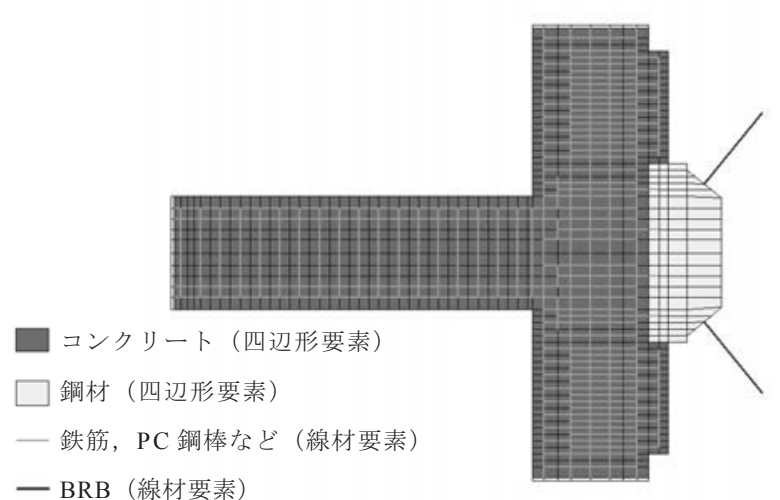

（b）over モデル

\section{図 11 有限要素解析モデル}

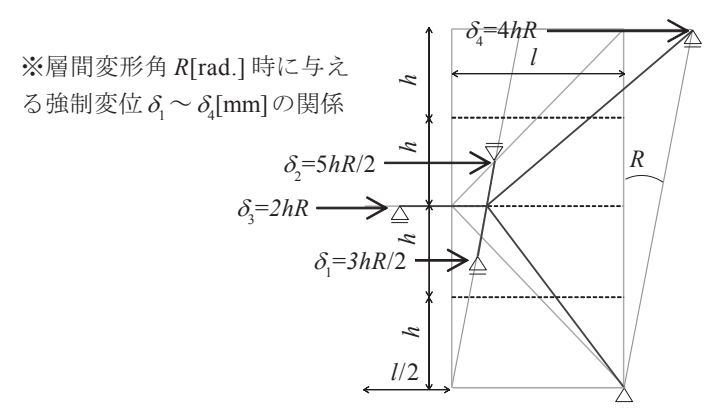

図 12 境界条件・載荷の詳細（over モデル）

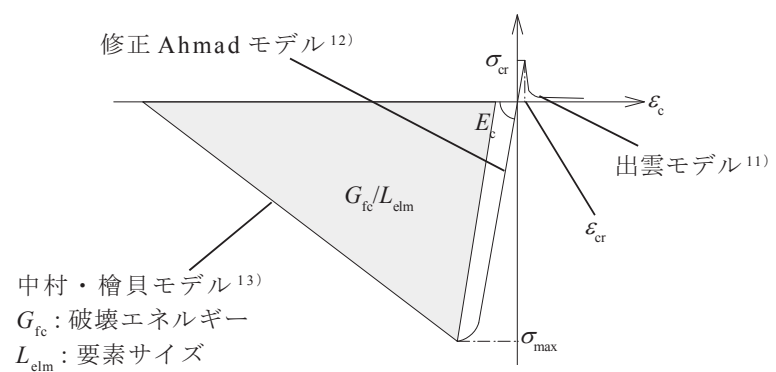

図 13 コンクリートの主応カ度一等価一軸ひずみ度関係 
正 Ahmad モデル12）を用い，最大強度後の特性は破壊エネルギに基 づく中村・檜貝モデル13) を用いた。破壊条件はKupfer ${ }^{14)} ら の 2$ 軸破 壊基準により決定した。ひび割れ後のせん断伝達特性には長沼の提 案モデル15) を用いた。このモデルは鉄筋比の関数となっており，鉄 筋を持たない要素に対して適用すると, せん断伝達効果が過小評価 される。したがって, ひび割れ後のせん断伝達を適切にするため, 四辺形要素にダミ一鉄筋を挿入し鉄筋比の情報を与えた。これによ り剛性には寄与せず, 鉄筋比の情報だけがコンクリートの構成則に 引き渡され, 適切なモデルで安定した解析を行うことができる。 ンクリートの設計基準強度 $\mathrm{Fc}$ は $36 \mathrm{~N} / \mathrm{mm}^{2}$, ヤング係数 $E_{\mathrm{c}}$ は $\mathrm{Fc}$ を基 に RC 規準 ${ }^{16)}$ によって算出し， $28300 \mathrm{~N} / \mathrm{mm}^{2}$ とした.
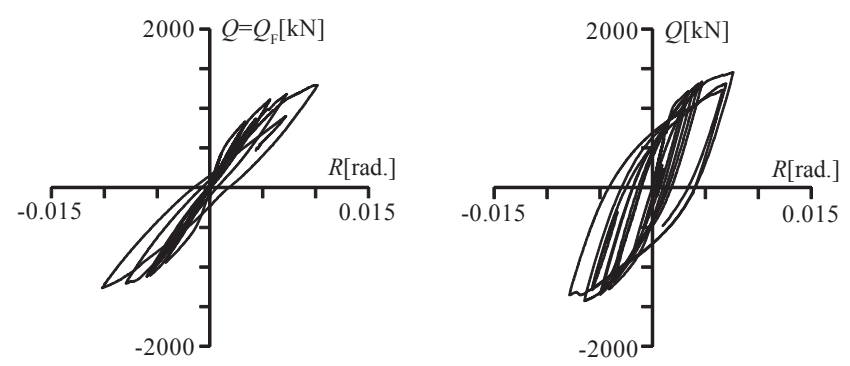

（i）下層の層せん断力

\section{(2) 鋼材}

柱と梁の主筋，せん断補強筋，コッター筋， BRB などの鋼材の履 歴特性には修正 Menegotto-Pint モデル 17) を用いた。鋼材のヤング係数 $E_{\mathrm{s}}$ は205000N/mm² とした.

\section{(3) 付着}

柱と梁の主筋，せん断補強筋，コッター筋と，コンクリート間は 完全付着とした。

\section{2. 有限要素解析結果}

\section{【荷重一層間変形角関係】}

基本建築物と over モデルの層せん断力 $Q$-層間変形角 $R$ 関係を図 14 に示す. over モデルでは主架構が負担する層せん断力 $Q_{\mathrm{F}}$ - 層間
(a) 基本建築物

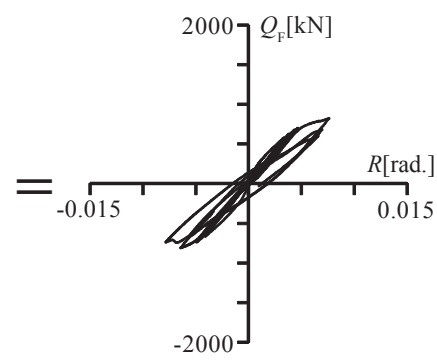

(ii）柱梁架構の負担分

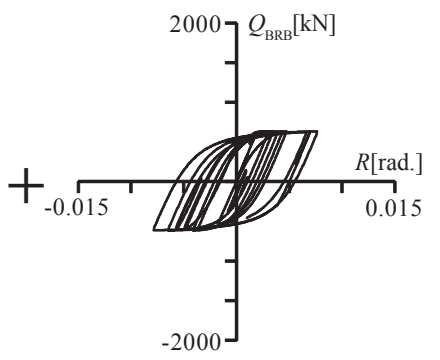

（iii）下層 BRB 軸力の 水平成分（1 層分）

(b) over モデル

図 14 荷重一層間変形角関係（ $t=0 \sim 30 \mathrm{~s} ）$

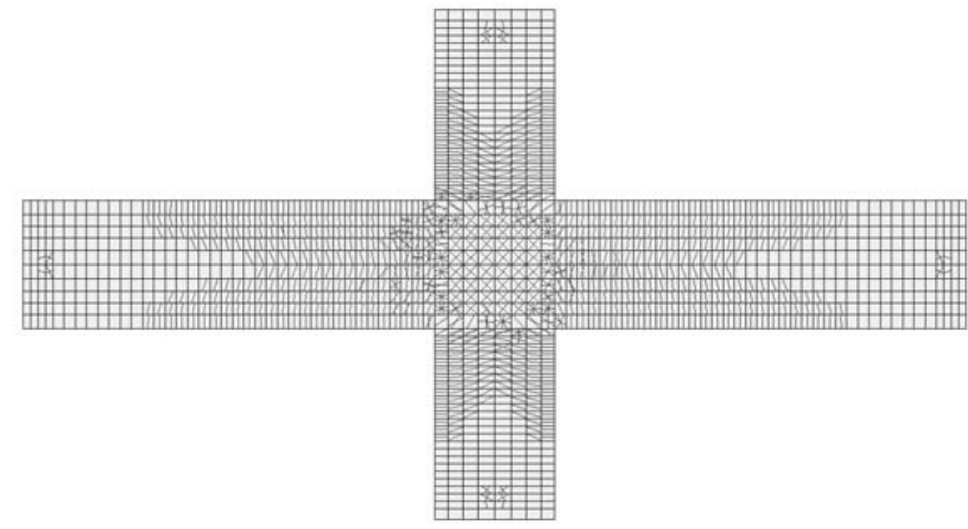

（a）基本建築物

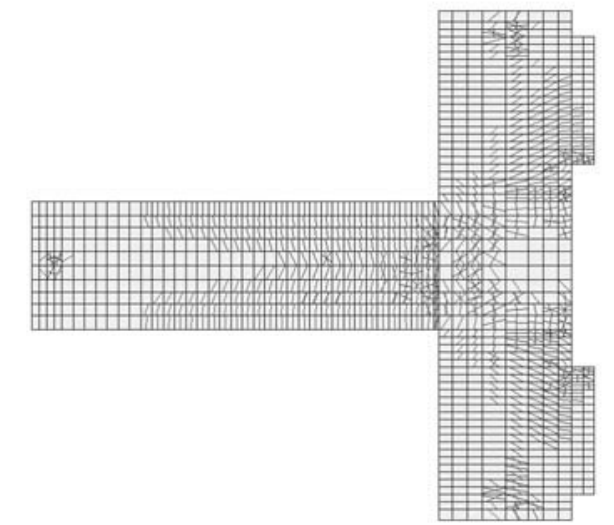

（b）over モデル

図 15 ひび割れ状況（ $t=20 \mathrm{~s}$ 時）

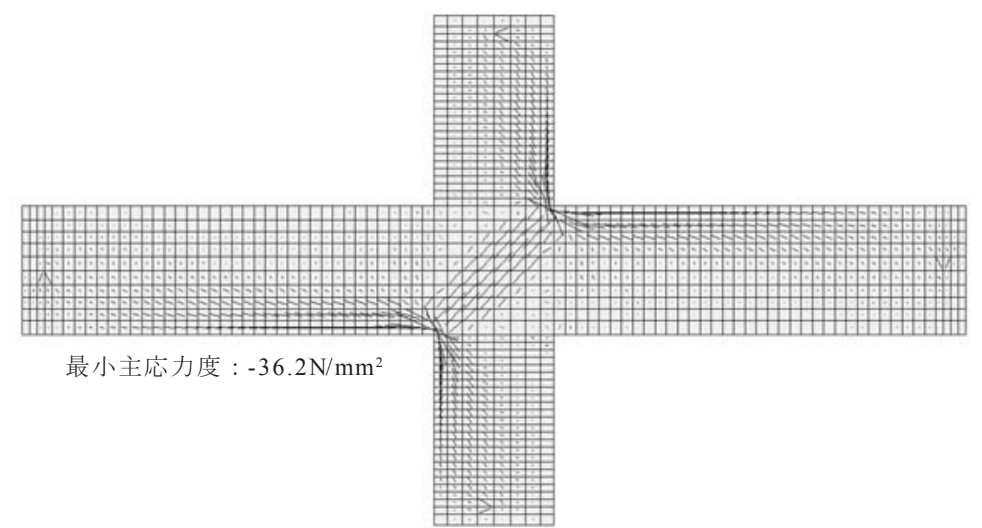

（a）基本建築物（ $R=1 / 175 \mathrm{rad}$. 時 $)$

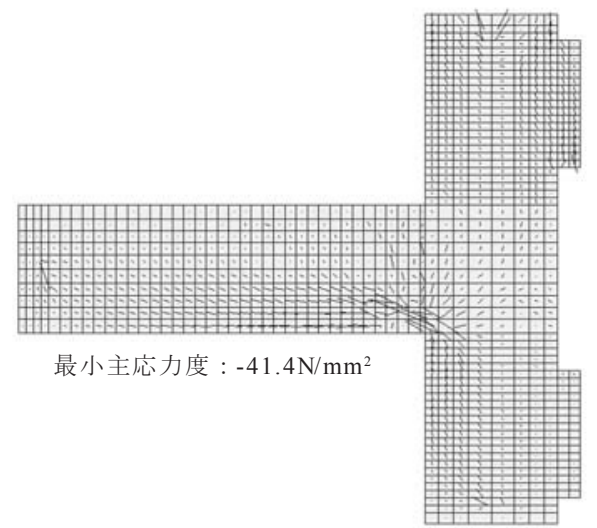

（b） over モデル $(R=1 / 213 \mathrm{rad}$. 時 $)$

図 16 最小主応力度分布（線長 7 倍） 
変形角 $R$ 関係，および下層 $\mathrm{BRB}$ の軸力の水平成分 $Q_{\mathrm{BRB}}$-層間変形角 $R$ 関係に分離して示す.

over モデルでは基本建築物に比べて, 主架構の履歴ループの面積 が小さく，損傷が抑制されている．また，over モデルのBRB は主架 構よりも小変形領域で降伏し, 安定したエネルギ吸収性能を発揮し た.

\section{【ひび割れ状況】}

基本建築物と over モデルの $t=20 \mathrm{~s}$ 時のひび割れ状況を図 15 に示す. 柱に着目すると，over モデルでは正負繰り返し荷重を受けているに も関わらず，柱心から BRB 側にのみ曲げひび割れが発生しており， 梁側には発生していない。これは既報》)においても確認された BRB 軸力の作用点が柱フェイスにあることで偏心曲げが生じ，正載荷時 には上層柱が, 負載荷時には下層柱が曲げ戻しを受けた影響であ る.

次いで, 柱梁接合部のひび割れに着目寸ると, 基本建築物ではパ ネルゾーンの全コンクリート要素に正負両方向の変形によるせん断 ひび割れが生じているのに対し, over モデルではひび割れの生じた 要素が少なく, せん断ひび割れの発生も抑制されていることが見て 取れる.これは, BRBによって層間変形が抑えられたことや, G.PL をアンカー PC 鋼棒によって柱に緊結したことが接合部の損傷を抑 制したと考えられる。したがって，本接合方法による RC 骨組への BRB の活用は層間変形を抑えるとともに柱部材および柱梁接合部の 損傷制御にも効果的である。

\section{【主応力度分布】}

基本建築物と over モデルの最大応答層間変形角時（基本建築物で は $R=1 / 175 \mathrm{rad}$, over モデルでは $R=1 / 213 \mathrm{rad}$.) の最小主応力度分布を図 16 に示す.

基本建築物では, 柱・梁部材の危険断面付近および柱梁接合部の 全域において大きな最小主応力度が生じている。一方, over モデル では, BRBの影響により最小主応力度は基本建築物よりやや大きい が, 柱・梁部材や柱梁接合部などの最小主応力度が小さい。した がって, 主応力度分布からも BRB を組み込むことで RC 骨組の損傷 が抑制されたことが分かる。

\section{【等価粘性減衰定数】}

基本建築物と over モデルに $R=1 / 400 ， 1 / 200 ， 1 / 150 \mathrm{rad}$. の層間変形角 において各 1 サイクルずつ与え, それぞれのモデルの $R=1 / 200,1 /$ $150 \mathrm{rad}$. サイクルにおける等価粘性減衰定数 $h_{\mathrm{eq}}$ を算出した. 荷重一 層間変形角関係を図 17 に, 等価粘性減衰定数 $h$ eq を表 5 に示寸。な お， over モデルにおける荷重に関して，BRB が負担する水平力は 1 層分に変換した值としている.

図 17 より, 基本建築物, over モデルともに負担する層せん断力
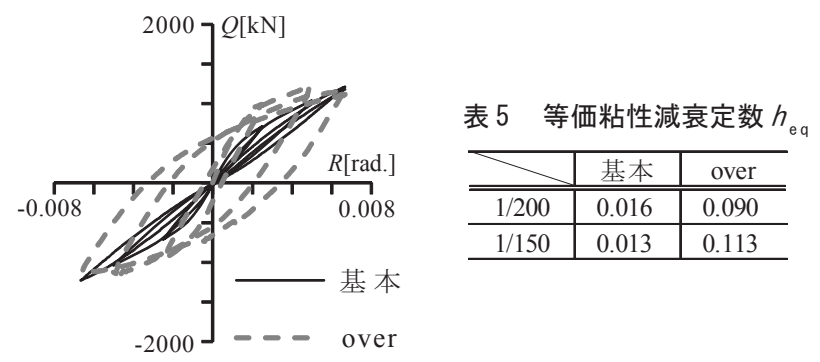

\begin{tabular}{c|c|c}
\hline & 基本 & over \\
\hline \hline $1 / 200$ & 0.016 & 0.090 \\
\hline $1 / 150$ & 0.013 & 0.113 \\
\hline
\end{tabular}

図 17 荷重一層間変形角関係
はほぼ同等であるが，履歴ループは over モデルの方が大きい，等価 粘性減衰定数 $h_{\mathrm{eq}}$ を比較すると, 対象とした部分架構において, $R=1 /$ $200 \mathrm{rad}$. 時には約 6 倍, $R=1 / 150 \mathrm{rad}$. 時には約 9 倍の減衰効果が付加で きていることが分かる. 前章の地震応答解析モデルでは 6 構面のう ち 2 構面の中央コア部のみにBRB を組み込んだが, 最大応答層間変 形角を約 $37 \%$ 低減できることが確認されている.

\section{BRB 接合部設計法}

\section{1. コッターの設計法}

筆者らは既報 ${ }^{6)}$ において, コッターのせん断抵抗機構を Strut-andTie Model（図 18）として表現し, 既往のコッターの耐力評価式を もとに修正評価式（式（1））を提案した.

$$
V_{\mathrm{u} \_ \text {mod }}=\sigma_{\mathrm{d}} b l \cos \theta
$$

本式はコッターのせん断耐力を精度よく評価できるが，実際の構造 物に適用し, 地震後の建築物継続使用および B R B 付け替えを考慮 すると, コッターを継続使用できる程度の損傷に留める設計とする 必要がある。そこで本章では前章で作成した有限要素解析モデルの コッター部に片振りの繰り返し力を与え, コッターの損傷状態を把 握し, 設計方法を検討する.

\section{【コッターの詳細およびパラメータ】}

前章に示したover モデルの 23 層のコッター詳細を図 19 に示す.

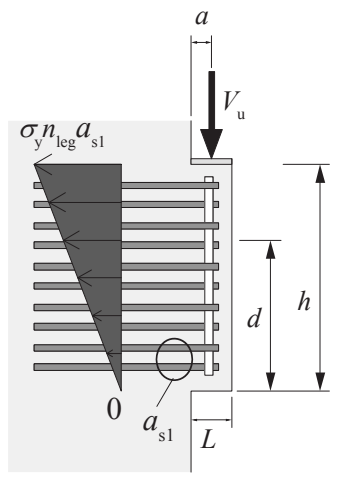

(a) コッターの形状

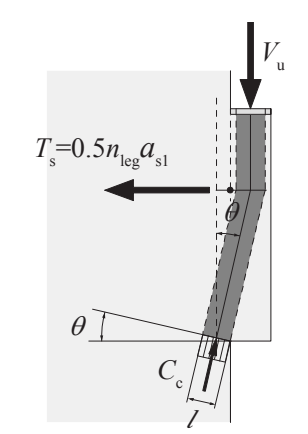

(b) Strut-and-Tie Model
図 18 コッターの耐荷機構6)

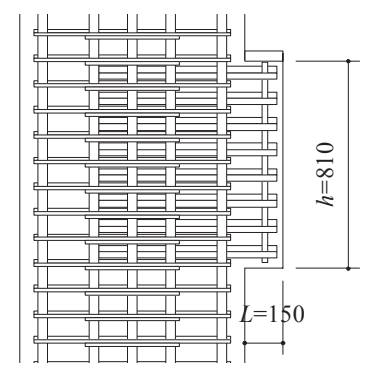

柱配筋図

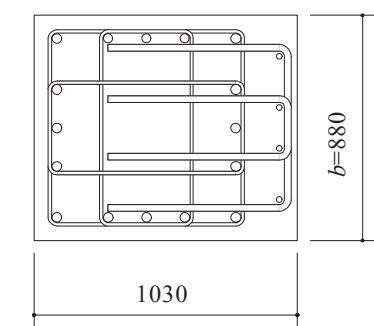

コッター断面図
図 19 コッター詳細（単位 $[\mathrm{mm}]$ )

\begin{tabular}{|c|c|c|c|}
\hline 表 6 & コッター & 峄析パ & ータ \\
\hline & $\mathrm{OC}$ & $\mathrm{CC}$ & $\mathrm{SC}$ \\
\hline$b \times h[\mathrm{~mm}]$ & \multicolumn{3}{|c|}{$880 \times 810$} \\
\hline$L[\mathrm{~mm}]$ & 150 & 150 & 150 \\
\hline $\mathrm{F}_{\mathrm{c}}\left[\mathrm{N} / \mathrm{mm}^{2}\right]$ & 36 & 48 & 36 \\
\hline コッター筋 & \multicolumn{2}{|c|}{$\mathrm{D} 25$} & D22 \\
\hline$V_{\text {u cal }}{ }^{6)}[\mathrm{kN}]$ & 5234 & 6168 & 4758 \\
\hline
\end{tabular}

(※コッター筋鋼種はSD295A, 本数・ピッチは $4 \times 8$ 列@100 $\mathrm{mm}$ ) 
本コッターは既報7) の部分架構実験に用いた試験体を基に寸法を 設定し, 上下層 BRB の降伏耐力 $(2000 \mathrm{kN} \times 2$ 本 $)$ の鉛直成分 $(\sin 50.9$ 。）に相当する力 $(3104 \mathrm{kN})$ に耐えうるように式（1）を用いて配 筋を決定した。本モデルを基準（以下， OC）とし，コンクリート 強度, コッター筋量, 載荷履歴をパラメータとしたパラメトリック スタディを行った．基準の OC に対してコンクリート強度を大きく したモデル（以下， CC），コッター筋量を減らしたモデル（以下， SC）である. パラメータ一覧を表 6 に示す。筆者らが提案した式 (1) を用いて評価したコッターのせん断耐力 $V_{\text {u_cal }}$ も併せて示している.

\section{【載荷】}

載荷は．それぞれのモデルで，式（1）によるコッターのせん断 耐力評価值 $V_{\text {u_cal }}$ の 0.50 倍, または 0.67 倍, または 0.80 倍の荷重にお いて, 片振りで繰り返し 2 サイクル与え, その後プッシュオーバー を行った.

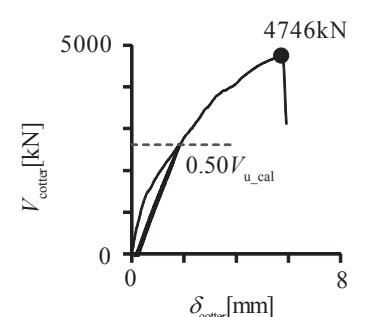

(i) $0.50 V_{\text {u_cal }}$

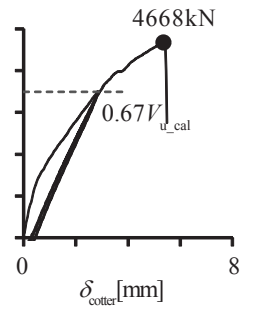

(ii) $0.67 V_{\text {ucal }}$ (a) OC モデル

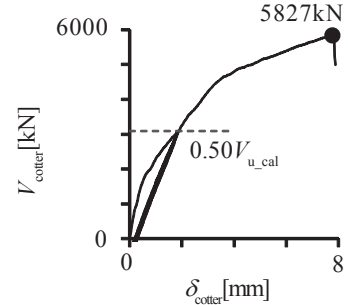

(i) $0.5 V_{\text {ucal }}$

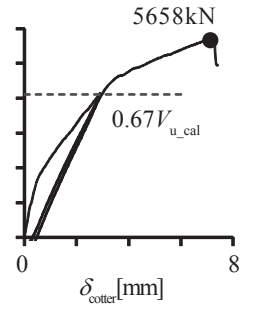

(ii) $0.67 V_{\text {ucal }}$

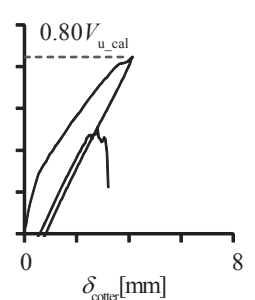

(iii) $0.80 V_{\text {u_cal }}$ (b) $\mathrm{CC}$ モデル

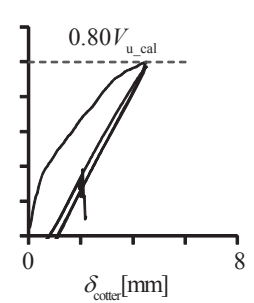

(iii) $0.8 V_{\text {u_cal }}$

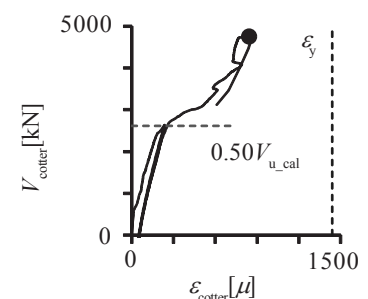

(i) $0.50 V_{\text {u cal }}$

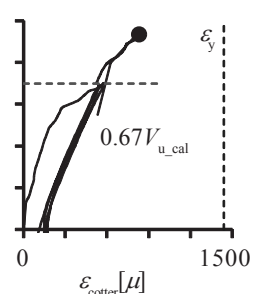

(ii) $0.67 V_{\text {u_cal }}$
図 20 コッターの荷重一変位関係

(a) OC モデル

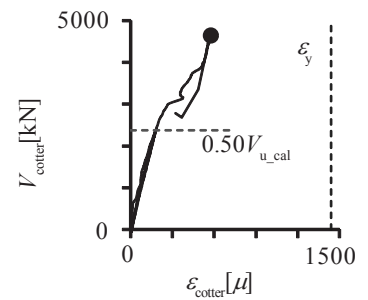

(i) $0.50 \mathrm{~V}$

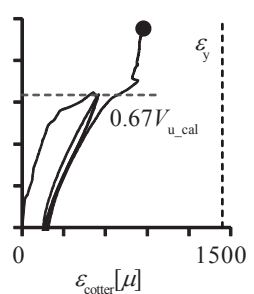

(ii) $0.67 V_{\text {u cal }}$

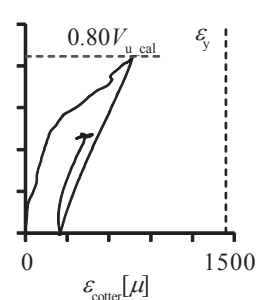

(iii) $0.80 V_{\text {u_cal }}$ (b) $\mathrm{SC}$ モデル

図 21 コッター筋の荷重一ひずみ度関係

\section{【片振り繰り返し載荷に対するコッターの応答性状】}

$\mathrm{OC}$ モデルと CC モデルのコッターの荷重一変位関係を図 20 に, OC モデルと SC モデルの加力点最近傍のコッター筋の荷重一ひずみ度 関係を図 21 に示寸. また, OC モデルに $0.67 V_{\text {u cal }}$ で繰り返し 2 サイ クル与え, その後のプッシュオーバーサイクル中の $0.50 V_{u_{\text {ucal }}}$ 時, $0.67 V_{\text {u_cal }}$ 時, および最大荷重時のコッター部コンクリートにおける 最小主応力度分布を図 22 に示寸.

解析におけるコッターのせん断耐力 $V_{\text {u_ana }}$ は, OC モデルは $4668 \mathrm{kN}$, $\mathrm{CC}$ モデルは $5658 \mathrm{kN}, \mathrm{SC}$ モデルは $4627 \mathrm{kN}$ となり, 式（1）による評 価値 $V_{\text {u_cal }}$ よりやや低い值となったが概补良好に評価できている，な お, $V_{\text {u ana }}$ は載荷履歴によって異なっており, 小さい方をせん断耐力 とした。繰り返し載荷による剛性低下に着目すると, いずれのモデ ルにおいても処女載荷時にはひび割れ発生により剛性が低下寸る.

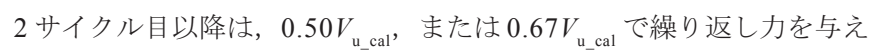
た間はほぼ弾性的な挙動であった。 $0.80 V_{\text {u_cal }}$ の繰り返し力を与えた 場合はコンクリートの損傷が大きくなり, コッターが破壊した。

図 21 から, コッター筋については $0.50 V_{\text {u_cal }}$ での繰り返し載荷では いずれのモデルもほぼ弾性的な挙動を示している．0.67V $V_{\text {u cal }}$ での繰 り返し力を与えた場合は処女載荷時にひずみ度が少し増大し，2 サ イクル目以降はやや剛性が低下していることが見て取れる.

コッター部コンクリートにおける最小主応力度に着目すると, 最 大荷重時にはコンクリート強度の $36 \mathrm{~N} / \mathrm{mm}^{2}$ を超えており, コンク リートの圧壊でコッターの最大耐力が決まったと考えられる。ま た, $0.67 V_{\text {u_cal }}$ 時の最小主応力度は $31.7 \mathrm{~N} / \mathrm{mm}^{2}$ とコンクリート強度の約 9 割にあたる最小主応力度が生じている. 一方, $0.50 V_{\text {u_cal }}$ 時の最小主 応力度は $23.4 \mathrm{~N} / \mathrm{mm}^{2}$ とコンクリート強度の $2 / 3$ 以下に抑えられてい ることが分かる。

以上のことから， $0.50 V_{\text {ucal }}$ での繰り返し載荷時にはコンクリート がひび割れた後もコッターは弾性的な挙動であり, 継続使用が可能 であると考えられる。したがって, コッターの設計においては, コ ンクリートのひび割れは許容することとし, 式 (1) から得られる せん断耐力 $V_{\text {u_cal }}$ に安全係数として 0.5 を考慮して設計する. なお, こ こでは, アンカーPC 鋼棒で締め付けていることによって G.PL と柱 間に作用する摩擦抵抗寄与分は考慮せずに設計する ${ }^{7)}$.

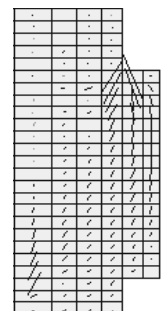

最小主応力度 : $-23.4 \mathrm{~N} / \mathrm{mm}^{2}$

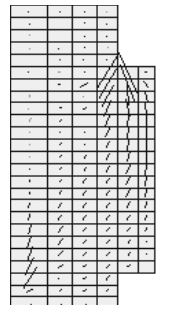

最小主応力度 : $-31.7 \mathrm{~N} / \mathrm{mm}^{2}$

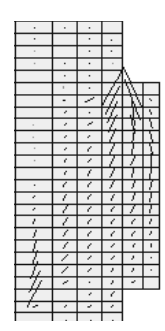

最小主応力度

$-41.8 \mathrm{~N} / \mathrm{mm}^{2}$
22 コッター部コンクリートの最小主応力度分布（線長 7 倍）
表 $7 \quad B R B$ 接合部の接合部係数 $\beta$ 18)

\begin{tabular}{c|c|c|c|c}
\hline \multirow{2}{*}{ 心材鋼種 } & \multicolumn{4}{|c}{ G.PL鋼種 } \\
\cline { 2 - 5 } & SN400B & SN490B & SS400 & SM490 \\
\hline \hline LY100 & 2.55 & 2.70 & 2.90 & 2.95 \\
\hline LY225 & 1.25 & 1.30 & 1.45 & 1.45 \\
\hline SN400B & 1.50 & 1.60 & 1.70 & 1.75 \\
\hline SN490B & 1.30 & 1.35 & 1.50 & 1.50 \\
\hline
\end{tabular}




\section{【コッターの設計式の提案】}

前述した通り, コッターの設計は上下層 BRB 軸力の合計の鉛直 成分が式（1）から得られるせん断耐力 $V_{\mathrm{u} \text { cal }}$ に安全係数 0.5 を乗じた 值以下となるように設計する。また，設計時は繰り返し加力による BRB の耐力上昇を考慮するとともに, G.PL 鋼材を弾性範囲に留める 必要がある. 鋼構造接合部設計指針18) に従い, それらを考慮した 表 7 に示寸 BRB 接合部の接合部係数 $\beta$ も含めた設計式とする. した がって, コッターの設計式 $V_{\text {u_design }}$ は式 (2) とする.

$$
V_{\mathrm{u}_{\text {_design }}}=0.5 \sigma_{\mathrm{d}} b l \cos \theta>\beta\left(P_{\mathrm{BRB}_{-} \_ \text {up }}+P_{\mathrm{BRB}_{\text {___low }}}\right) \sin \alpha
$$
ここで $P_{\text {BRB y_up }}$ : 上層 BRB の降伏耐力, $P_{\text {BRB y_low }}$ : 下層 BRB の降伏耐力, $\alpha:$ BRB 取り付け角度である.

\section{2. アンカーPC 鋼棒の設計法}

筆者らはこれまでに, 低層（3 層）および中層（12 層）の RC 骨 組にBRB を取り付けた場合の地震応答解析を行った ${ }^{19), 20)}$. これら の結果, 動的挙動時には BRB 軸力の正負が入れ替わる際に, BRB 接 合部に約 1 本分の BRB 降伏耐力に相当する引張力が生じることが分 かっている．静的な釣り合いを考慮しても，上下層 BRB の降伏耐 力が切り替わる中間層や BRB 最上層では, BRB 接合部に降伏耐力 の差分による水平成分が作用する.

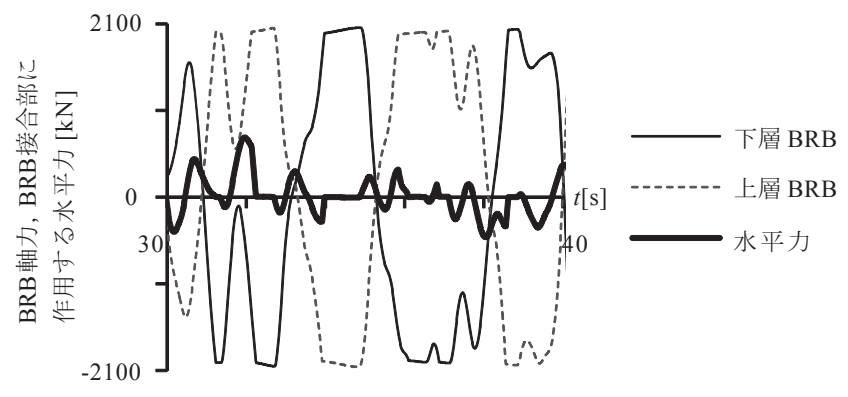

図 23 上下層 $B R B$ の応答軸力, BRB 接合部に作用する水平力

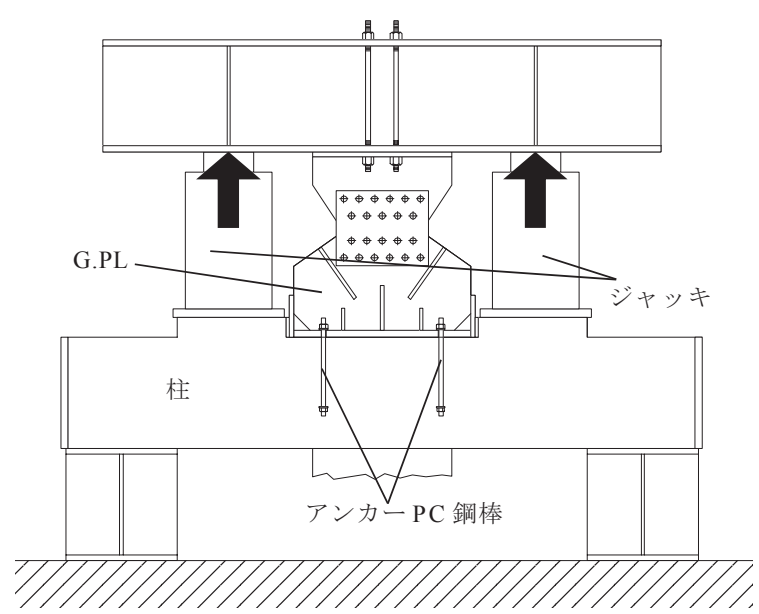

図 24 要素実験セットアップ

表 8 要素実験試験体諸元

\begin{tabular}{|c|c|c|c|}
\hline 試験体 & アンカー & $F_{\mathrm{y}} / F_{\mathrm{u}}[\mathrm{kN}]$ & ボル卜初期導入張力 \\
\hline 梁せい小 & 少ンカーボル卜 & & \\
\hline 梁せ & $\begin{array}{c}(\mathrm{M} 16) \\
\text { SNR490B }\end{array}$ & $54 /-$ & $30[\mathrm{kN}] \times 4$ 本 $=120[\mathrm{kN}]$ \\
\hline ア: & $\begin{array}{c}\mathrm{PC} \text { 鋼棒 }(\phi 13) \\
\mathrm{C} \text { 種1号 }\end{array}$ & 4 & $60[\mathrm{k \perp}$ \\
\hline
\end{tabular}

( $F_{\mathrm{y}}$ :ボルトの降伏耐力, $F_{\mathrm{u}}$ :ボルトの破断耐力 $)$

\section{【超高層 RC 建築物における BRB 接合部に作用する水平力】}

3 章で解析した over モデルの 23 層における上下層 BRB の告示波 (乱数) $(\mathrm{PGV}=75 \mathrm{~cm} / \mathrm{s})$ に対する応答軸力，およびその差分を図 23 に 示寸. 上下層 BRB 軸力の差分が最も大きくなった $t=30 \sim 40 \mathrm{~s}$ 時を示 している.

図 23 から, 最大で $700 \mathrm{kN}$ 程度の水平力が BRB 接合部に作用して いることが分かる. over モデルの BRB 降伏耐力の切り替わる層で は, さらに $1000 \mathrm{kN}$ 程度の引張力が加わることも想定される. 既報 19)，20）で詳細に検討した結果も含め，上下層に取り付ける BRB の約 1 本分の降伏耐力の水平成分に相当する力をアンカー PC 鋼棒に導 入することで, BRB 接合部に作用寸る水平力に対応できる.

\section{【アンカーP C 鋼棒の引張性状に関する要素実験】}

アンカー PC 鋼棒の引張性状を確認する目的で, 既報6) の部分架 構実験試験体を用いて, G.PL を介したアンカーPC 鋼棒の引張実験 を行った。

セットアップを図 24 に, 試験体諸元を表 8 に示す。変位は, 柱 と G.PL の相対変位（合計 6 箇所）を計測し，平均值を G.PL の浮き 上がり $\delta_{\mathrm{G} . \mathrm{PL}}$ とした. 載荷は左右 2 台のジャッキによって鉛直上向き に加力し, 上部の加力治具を介して, G.PL に引張力を作用させた.

G.PL の荷重一浮き上がり関係を図 25 に示す. 縦軸に G.PL の引張 力, 横軸に G.PL の浮き上がりを示す.いずれの試験体においても アンカーPC 鋼棒（もしくはボルト）は初期導入張力に達するまで 浮き上がりはほとんど生じず, 初期導入張力を超えると, G.PL の浮 き上がりが顕著になった，その後, アンカーボルトではボルトが降 伏し, 伸びが増加し, ひずみ硬化し始めたため実験を終了した。 ア ンカー PC 鋼棒では, PC 鋼棒が降伏して伸びが $2 \%$ 程度の時点で PC 鋼棒のネジ部が破断した。

\section{【アンカーPC 鋼棒の導入張力の決定方法】}

既報 199，20) および本論文における検討結果から，BRB 接合部に作 用する水平力は最大でも, 上下層に組み込んだ BRB の降伏耐力の 大きい方に対する水平成分程度と考えておけばよい. 既報7)で行っ た BRB を組み込んだ RC 部分架構の実験では, BRB 接合部に生じる 引張力には, アンカー $\mathrm{PC}$ 鋼棒を締め付けておくことで抵抗できる ことを確認している. また, 前節に示した要素実験からも, 提案し た BRB 接合部の水平耐力はアンカーPC 鋼棒の降伏によって決定さ れ, アンカー PC 鋼棒に導入した力に到達するまでは, 柱と G.PL の 離間はほとんど生じないと言える。したがって, PC 鋼棒の導入張 力 $P_{\text {anchor_design }}$ は式 (3) によって決定する.ここでも, コッターの設 計式と同様, 表 7 に示寸 BRB 接合部の接合部係数 $\beta$ を考慮したもの とする. (a) アンカーボルト

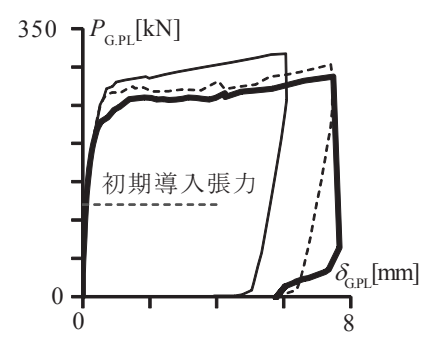

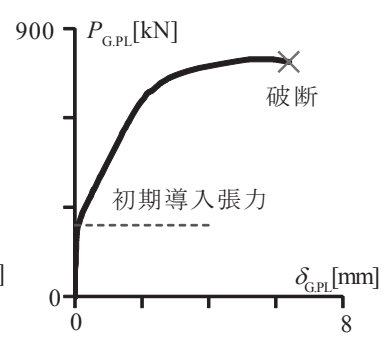

(b) アンカー PC 鋼棒
図 25 G.PL の荷重一浮き上がり関係 
$P_{\text {anchor_design }}>\beta \cdot \max \left(P_{\text {BRB_y_up }}, P_{\text {BRB_y_low }}\right) \cdot \cos \alpha$

なお, 本研究で提案した BRB 設置方法を用いて $\mathrm{RC}$ 梁を省略しても, 現実的には軽微な鉄骨梁（スラブ受け）を設置することになると考 えられる．既報 ${ }^{7)}$ の実験では，軽微な鉄骨梁を設置することでも 引張力への抵抗に寄与寸ることが分かっているが，この抵抗寄与分 は考慮せずに設計することで B R B 接合部の安全性を確保すること ができる。

\section{6. 結}

本論文では BRB を組み込んだ超高層 $\mathrm{RC}$ 建築物の地震応答解析を 行った。また，既報 ${ }^{7)}$ で作成した有限要素解析モデルを用いて制 振効果を検討した。ささらにBRB 接合部の具体的な設計法を提案し た。本論文で得られた結論を以下にまとめる.

1 ）本論文で計画した 2 層をまたぐ形でBRB を設置した over モデル は，各層にBRB を設置した each モデルに比較して，BRBの設置 数を減らし，かつコア部周囲の RC 梁を省略したが，ほぼ同等 の応答層間変形角低減効果が確保された。したがって, 本架構 計画はより合理的な BRB 設置形式であると言える。

2 ) 地震応答解析結果における梁の履歴挙動より, 基本建築物と each モデルでは梁主筋が降伏したが，over モデルでは弾性範囲 であった。塑性率で比較すると，over モデルでは基本建築物に 比べて $42 \%$ の変形低減効果があり, each モデルと比較しても $17 \%$ 変形が低減できた。したがって，BRB を組み込むことで RC 骨組 の変形が低減できることが分かった。また，BRB の履歴挙動よ り，2 層をまたぐようにBRBを設置することで，BRB の変形を 増大させ，上層部においても BRB を有効に機能させられること が分かった。

3 ) 有限要素解析結果より, 筆者らが提案したコッターとアンカー $\mathrm{PC}$ 鋼棒を用いた BRB 接合方法，および over モデルの設置計画を 用いた RC 骨組への BRB の活用は， RC 建築物の層間変形を抑え るとともに柱・梁部材および柱梁接合部の損傷制御にも効果的 である．等価粘性減衰定数 $h_{\mathrm{eq}}$ を比較すると，対象とした部分架 構において, over モデルでは基本建築物よりも $R=1 / 200 \mathrm{rad}$. 時に 約 6 倍, $R=1 / 150 \mathrm{rad}$. 時に約 9 倍の減衰効果が付加できた. 地震応 答解析モデルでは 6 構面のうち 2 構面の中央コア部のみに B RB を組み込んだが，最大層間変形角を約 $37 \%$ 低減できた。

4 ）筆者らがこれまでに提案してきたコッターとアンカーPC 鋼棒 を用いた BRB 接合部に関して，解析および要素実験を行い，具 体的な設計法を示した。

\section{謝辞}

本研究は, 株式会社熊谷組構造設計部増子寛部長, および構造設 計部の皆様から設計上・施工上の観点からの貴重なご意見を頂きま した。ここに記して謝意を表します。

\section{参考文献}

1) 中山健志，橋本真一：着工統計資料からみた超高層建築物の供給実態と 市場に関する考察, 日本建築学会大会学術講演梗概集 F-1 分冊, pp.1405$1406,2011.8$

2）宮下真一，公塚正行：超高層 RC 造骨組における柱の変動軸力を考慮し た弾塑性解析 その 1 静的弾塑性解析, 日本建築学会大会学術講演梗 概集 C 分冊, pp.763-764, 1990.10

3 ）公塚正行, 宮下真一, 土生川恵洋, 山本俊彦, 大滝健 : 超高層 RC 造骨 組における柱の変動軸力を考慮した弾塑性解析 その 2 構造実験との 対応, 日本建築学会大会学術講演梗概集 C 分冊, pp.913-914, 1991.9

4) 丸田誠，木村暁子：高強度材料を用いた鉄筋コンクリート柱の曲げせん 断実験，コンクリート工学年次論文集，Vol.24，No.2，pp.283-288，2002.7

5 ）西村勝尚, 福本義之, 和田裕介：連結制振構造を適用した超高層 $\mathrm{RC}$ 造 建築物の制振効果，日本建築学会技術報告集，第 14 巻，第 28 号，pp.417$422,2008.10$

6) 毎田悠承, 吉敷祥一, 野々山昌峰, 曲哲, 前川利雄, 濱田真, 坂田弘安, 和田章 : 座屈拘束筋違を取り付けるための接合部を有する部分架構の実 験 - 鉄筋コンクリート骨組への座屈拘束筋違の活用に関寸る研究 その 1 -, 日本建築学会構造系論文集，第 681 号，pp.1737-1746，2012.11

7 ）毎田悠承, 吉敷祥一, 曲哲, 前川利雄, 濱田真, 坂田弘安, 和田章: 座 屈拘束筋違を組み込んだ鉄筋コンクリート部分架構の力学挙動 - 鉄 筋コンクリート骨組への座屈拘束筋違の活用に関する研究 その 2 -, 日本建築学会構造系論文集, 第699号, pp.603-612, 2014.5

8 ）出水俊彦, 斉藤大樹, 福山洋, 森田高市, 向井智久, 濱田真, 菊田繁美, 金川基，薬研地彰，佐々木仁：長周期地震動を受ける RC 造超高層建築 物の構造性能 その 1 地震応答性状, 日本建築学会大会学術講演梗概 集 C-2 分冊, pp.499-500, 2009.8

9) MIDAS Information Technology Co., LTD.: MIDAS Gen Ver. 830, 2014.7

10) 伊藤忠テクノソリューションズ (株) : FINAL/V11 HELP, 2011.7

11 ) 出雲淳一, 島弘, 岡村甫 : 面内力を受ける鉄筋コンクリート板要素の解 析モデル，コンクリート工学論文，No.87，Vol.9-1，pp.107-120，1987.9

12) 長沼一洋：三軸圧縮下のコンクリートの応力ーひずみ関係, 日本建築学 会構造系論文集，第474 号, pp.163-170, 1995.8

13) Hikaru Nakamura and Takeshi Higai: Compressive Fracture Energy and Fracture Zone Length of Concrete, Seminar on Post-peak Behavior of RC Structures Subjected to Seismic Loads, JCI-C51E, Vol.2, pp.259-272, 1999.10

14) Kupfer H.B.and Gerstle K.H.: Behavior of Concrete under Biaxial Stress, Journal of the Engineering Mechanics Division, ASCE, Vol. 99, No. EM4, pp.853-866, 1973.8

15 ）長沼一洋：平面応力場における鉄筋コンクリート板の非線形解析モデル 鉄筋コンクリート壁状構造物の非線形解析手法に関寸る研究 その 1，日本建築学会構造系論文報告集，第421 号，pp.39-48，1991.3

16）日本建築学会：鉄筋コンクリート構造計算規準・同解説 2010, 2010.6

17) Ciampi, V., Eligehausen, R., Bertero, V.and Popov, E.: Analytical Model for Concrete Anchorages of Reinforcing Bars Under Generalized Excitations, Report No. UCB/ EERC-82/23, Univ. of California, Berkley, 1982.11

18）日本建築学会: 鋼構造接合部設計指針, 2001.11

19）曲哲, 毎田悠承, 野々山昌峰, 吉敷祥一, 前川利雄, 仲宗根淳, 坂田弘 安, 和田章 : 鉄筋コンクリート骨組への座屈拘束筋違の活用に関する研 究 その 5 地震応答解析による基礎検討, 日本建築学会大会学術講演 梗概集 C-2 分冊, pp.675-676, 2011.8

20) Zhe Qu, Yusuke Maida, Shoichi Kishiki, Hiroyasu Sakata, Akira Wada, Toshio Maegawa and Makoto Hamada: Numerical Assessment of Seismic Performance of Continuously Buckling Restrained Braced RC Frames, Proc. 15th World Conference on Earthquake Engineering, in USB memory, 2012.9 


\title{
SEISMIC RESPONSE CONTROL OF SUPER HIGH-RISE RC BUILDINGS UTILIZING
} BUCKLING RESTRAINED BRACES AND THE DESIGN OF BRACE CONNECTIONS

- Applications of buckling restrained braces in reinforced concrete frames Part 3 -

\author{
Yusuke MAIDA ${ }^{* 1}$, Toshio MAEGAWA ${ }^{* 2}$, Toshihiko DEMIZU ${ }^{* 3}$, \\ Makoto HAMADA *4, Zhe $Q U^{* 5}$, Shoichi KISHIKI*6, \\ Hiroyasu $S A K A T{ }^{* 7}$ and Akira WADA*8 \\ ${ }^{* 1}$ Assistant Prof., Dept. of Architecture, Chiba University, Dr. Eng. \\ *2 General Manager, Architectural Structure Research Group, Technical Research \& Development Institute, KUMAGAI GUMI Co., Ltd., M. Eng. \\ *3 Principal Researcher, Technical Research Institute, Satokogyo Co., Ltd., M. Eng. \\ ${ }^{* 4}$ Deputy General Manager, Technical Research \& Development Institute, KUMAGAI GUMI Co., Ltd., M. Eng. \\ *5 Associate Researcher, Institute of Engineering Mechanics, CEA, Ph. D. \\ ${ }^{* 6}$ Associate Prof., Structural Engineering Research Center, Tokyo Tech, Dr. Eng. \\ ${ }^{* 7}$ Prof., Dept. of Architecture and Building Engineering, Tokyo Tech, Dr. Eng. \\ *8 Prof., Emeritus, Tokyo Tech, Dr. Eng.
}

Buckling restrained braces (BRBs) have been widely used as energy-dissipating devices to retrofit existing reinforced concrete (RC) frames in Japan. Some effort has also been devoted to applications of BRBs in newly-built RC moment-resisting frames, where efficient and reliable connections between the BRBs and the concrete components become an important issue. Insufficient connection may deform excessively during major earthquakes so as to impair the efficiency of BRBs to dissipate earthquake energy. Poorly-detailed connections may also subject the surrounding concrete components to complicated tensile and shear forces and degrade their seismic performance.

Accordingly, the authors suggested a continuously buckling restrained braced frame (CBRBF) system in which the BRBs are arranged in the form of a Warren truss. The BRBs in the adjacent stories share the same gusset plate, which is fastened to the concrete beam-to-column joint by prestressing bolts and is kept by a pair of RC corbels that project from the column surface. In such a manner, the prestressing bolts are mainly responsible to resist the horizontal force while the RC corbels the vertical one. The corresponding BRB connection details in the CBRBF system have been confirmed effective through cyclic loading test and FE analysis of RC subassemblies with BRBs. However, the subassemblage tests and corresponding analysis did not provide insight into the dynamic behavior of the whole building.

In this paper, the seismic response control of BRBs in super high-rise RC buildings subjected to earthquake ground motions is investigated by nonlinear time history analysis. The analysis model is a 36 stories super high-rise RC building. A bare frame structure is used as a reference model. The parameter of the analysis was the configuration of the BRBs. Two kinds of seismic response controlled building models were examined. In one model, the RC frame was braced by BRBs in each story (each model) and in the other one, each BRB spanned over two stories (over model). The RC beams in the braced span of the over model were abandoned. By comparing the maximum story drift ratio of the reference model with the braced ones, the seismic response control was confirmed for both the each model and the over model. In addition, the over model exhibited almost the same seismic response control as compared to the each model, although the number of BRBs was significantly reduced and the RC beams in the braced span were abandoned. In addition, the seismic response control of BRBs in RC buildings is investigated by FE analysis. Finally, test and analysis were carried out about BRB connection using corbel and the anchor PC rod which the author suggested. According to the results of the test and analysis, the design of brace connections was suggested. 